\title{
Professional football clubs retail branding strategies
}

\section{Adam Szymoszowskyj, Mathieu Winand, Dimitrios Kolyperas \& Leigh Sparks}

To cite this article:

Szymoszowskyj A., Winand M., Kolyperas D. \& Sparks L. (2016). Professional Football Clubs Retail Branding Strategies, Sport, Business, Management: An International Journal. 6:5 DOI: 10.1108/SBM-09-2016-0048

Purpose: While some football clubs are recognised as popular brands, little is known about the way they leverage their brand in their merchandise retailing. This study draws on brand equity and supply chain management to address this gap by investigating retail branding strategies used by professional football clubs. In particular, it analyses the type of product merchandised, the reasons for selling certain products and the ways through which football clubs merchandise, including their partners in distribution channels.

Design/methodology/approach: A qualitative approach was undertaken involving content analysis of 22 Scottish professional football clubs' websites and annual reports, and semi-structured interviews with seven football clubs retail managers and four supply chain partners. Transcribed data was coded and thematically organised through an inductive process using the qualitative data analysis software NVivo 10.

Findings: Three types of merchandise have been identified, basic, fashion and short season. Building brand equity is considered the main motive for retailing merchandise. Some football clubs use intermediaries or outsourcers to respond to sudden consumer demands and to ensure high levels of service, whereas others have an integrated supply chain which allows for greater control.

Research limitations/implications: This paper contributes to the discussion on the role of retailing in football club brand equity. It suggests initiating intermediaries in the distribution channels to build brand equity thus enabling clubs to become more responsive to consumer demand.

Originality/value: This is the first paper to look at retail branding strategies of professional football clubs.

Keywords: brand equity, supply chain, distribution channels, retail branding strategies, football clubs 


\section{Introduction}

Over the past decades the football industry has experienced dramatic commercial growth and rapid change. The twenty most valuable football clubs in the world are now worth an average of $€ 1.08$ billion, double that of five years ago (Forbes, 2015). Such clubs have developed into powerful brands and have benefited by steadily increasing commercial revenues in areas including television and new (social) media rights (Boyle et al., 2002; Rowe, 1995), sponsorship and partnership generation, urban (stadium) regeneration, and licencing and retailing of merchandise (Hamil and Chadwick, 2010; Kolyperas and Sparks, 2011; Morrow, 2003, 2006). The recent Deloitte Money League report (2016) provides further insights on the three key streams of revenue in the wealthiest football clubs in the world, namely match day revenue (gate receipts), broadcasting revenue (domestic and international) and commercial revenue (merchandise and sponsorship). Over the period between 2004 and 2013, commercial revenues including sponsorship and merchandise are the only areas demonstrating proportional growth in terms of the overall financial performance of football clubs. Notably, certain football clubs from the same national context and league (i.e. Barcelona FC and Athletic Madrid or Manchester United and Tottenham Hotspurs) demonstrate large discrepancies in terms of commercial revenues; a fact that can be attributed to their different global brand image and positioning. This also underscores that success on the pitch helps success off it, in that stronger brand equity can generate fans, fans can draw media and media in turn can draw sponsors.

Operational management in a football club is certainly not an easy exercise. Due to their stakeholder embedded nature and cultural origins, football clubs are context-specific, often ebbing and flowing between profit and utility maximization (Morrow, 2003). They have evolved from focusing on one-off production spectacles (the match lasting 90 minutes) into multi-purpose retailing hubs where consumer, cultural, political and commercial interests 
interact throughout the year. As a result, more and more clubs have realized the benefits of effective retailing branding strategies (Couvelaere and Richelieu, 2005; Sparks, 2007, 2010; Worsley, 2001) and the unique role branded merchandise can play in furthering brand equity (Islam and Deegan, 2013; Motion et al., 2003). Barcelona FC is recognised as a good example of a professional football clubs that successfully leverages its brand in their merchandise retailing (Richelieu and Pons, 2006).

There is a large body of research on retail branding strategies generally in sectors including grocery (Burt and Sparks, 2003) and fashion (Birtwistle and Freathy, 1998). However, branding research, particularly that focusing on retailing or merchandising has lagged behind practical developments in the football industry, with the exception of work carried out by Couvelaere and Richelieu (2005). Further research is needed to understand the unique nature and role of retail branding strategies undertaken by professional football clubs, i.e. a football club's plans and actions to retail its merchandise while leveraging its own football club's name as a brand. While attention has focused on sport management and marketing matters enhancing our understanding of how sport organisations including football clubs can develop their brand and subsequent business and social position (including CRM [Adamson et al., 2006.], financial accounting [Morrow, 2003], CSR and sustainability [Kolyperas et al., 2015]), few insights are available on how football clubs manage their retail operations and partners, and the consequences this might have on their brand equity.

Retail branding in team sport organisations and football clubs in particular is of timely research interest. Indeed, while some football clubs have become powerful global identity (retail) brands (i.e. opening stores outside their immediate local sphere and providing new hybrid offerings that include products/services and/or even symbolic consumption i.e. travel insurance packages, tours and cemeteries for die-hard fans), other clubs have not sought to organise and exploit their brand potential in this way. This generates research interest into the 
causes and effects of effective retail branding among football clubs. Furthermore, the peculiar nature of professional football (in that football is performance-based, appeals to different demographics, and operates in cycles and seasons) affects product assortment, supply chain and distribution (Dolles and Söderman, 2013). Such market dynamism in terms of time (seasonality) and demand (performance) directly affects new product development, assortment, variation, sourcing, and product life cycles, and includes elements of co-branding with manufacturers that affect the development of brand equity (Couvelaere and Richelieu, 2005; Worsley, 2001). There are risks of stock obsolescence, amplified if one considers other dynamics of the market such as the transfer of star players (in multiple periods before, during or after a season), hooliganism incidents, and betting scandals that affect how performance on the field is translated into performance off it.

Hence, this exploratory study aims to investigate the dynamic, diverse and interconnected world of retail and branding in football clubs, including product selection and the way football clubs obtain and distribute their branded merchandise (i.e. logistic considerations in downstream and upstream activities). By examining retail branding strategies deployed by professional football clubs in a particular national context (Scotland), this paper contributes to the literature on brand equity and retailing insights.

The paper is structured into five main sections. Following this introduction, the second section provides a review of key concepts related to retail branding in football clubs, and challenges they may pose. The third section describes the qualitative research design undertaken. The fourth section presents the findings. The last section discusses key findings and provides managerial implications of the study, whilst future research avenues are also set out. 


\section{Professional football clubs as retail brands}

\section{Brand equity in professional football clubs}

Over the years, academics and managers have used various definitions to understand brand equity; some approach it from a financial point of view (Kapferer, 2010), whereas a more dominant interpretation focuses on a consumer behaviour oriented perspective (Keller, 2001; 2003). Brand equity has been defined as the marketing effects uniquely attributable to the brand - that is when certain outcomes result from the marketing of a product or service because of its brand name that would not occur if the same product or service did not have that name (Keller, 1993: 1). Aaker and Joachimsthaler (2000) see brand equity as assets linked to brands and the symbolic thematic space these occupy that add to or subtract from a product or service.

As the game of football has become the global and commercial phenomenon that it is today, a growing number of football clubs have enlarged commercially to become multichannel retailing brands. While the core product of football clubs remains the production of sporting events, secondary product categories and brand extensions have gained momentum as a result of a variety of commercialization and marketing activities around such events (Bobby, 2002; Burton and Howard, 1999; Couvelaere and Richelieu, 2005; Shannon, 1999). Strong football brands initiate fan, local community, media, and sponsors' interest (Richelieu and Pons, 2006). Such brands are currently taking different forms and shapes (for example, Barcelona FC positioning of itself as being more than a club). Gladden et al. (1998; 2001) see various antecedents that impact on brand equity in sport organisations including team-related characteristics such as the signing or transfer of star players (which can turn jerseys into cash cows or obsolete wasteful stock), organisation-related matters including a club's tradition, reputation and culture, along with market-related conditions such as media coverage, 
economic situation and geographic location. As the authors explain 'while (athletic) success may be fleeting, a focus on commitment to customers is not' (Gladden et, 2001: 301).

In football, fans are regarded as an important customer group that is targeted by football clubs in their retailing strategies (Richelieu and Pons, 2006). However, like in many sports, the on-field seasonal performance found in football and the dynamics in terms of consumer demand this triggers has implications on the types of product, their availability and perishability, as well as the motivation for purchasing football club merchandise. A branded football merchandise good (e.g. a shirt) is not simply a product but rather a fashion/lifestyle good and identity statement. As such, football shirts are being marketed and consumed for their intangible feel-good factors (e.g. an historical jersey associated with a particular football success is often more saleable) not their tangible quality characteristics (aesthetics or functionality). Often being utilised as a successful extension strategy to allow further fan affiliation (Tapp, 2004; Wilson and Liu, 2012), football shirts commonly attract a price premium (for more on price see BBC football price survey, 2015). They appeal to different social classes and various consumer demographics: die-hard fans who purchase as to fulfil social identity needs (Bristow and Sebastian, 2001; Couvelaere and Richelieu, 2005; Heere and James, 2007; Wakefield and Wann, 2006); younger generations seeking symbols through which to express loyalty and a sense of belonging (Couvelaere and Richelieu, 2005; Gustafson, 2001; Sparks, 2010); through to latent support and older 'fair-weather' fans where the purchase is an expression of nostalgia (End et al., 2002; Wakefield and Wann, 2006). As a result, football club merchandise is fashion and time-dependent as well as performancerelated; fan demand may explode or disappear rapidly. In addition access to physical or virtual locations, instore and online atmosphere, pricing and promotion, cross and withincategory assortment, copyright infringements and brand dilution (Bill, 2004; Shemtov, 2007; Waelde et al., 2013) as well as co-branding (with sponsors and manufactures) and (complete 
or partial) outsourcing of retail unit operations (Davies et al., 2008; Fernie and Sparks 2014) add to the complexity of the retail environment modern football clubs find themselves in.

\section{Supply chain and retailing in professional football clubs}

As a result of increasing complexity, costs, and consumer expectations along with shorter product life cycles, supply chain management has developed in significance to become a key focus of the business/management discipline. A supply chain entails the interaction of different parties (suppliers, manufactures, intermediaries) that participate either directly or indirectly in meeting the needs of customers (Chopra and Meindl, 2007). This involves production points, logistics, distribution channels and retail stores which are subject to change from time to time as organisational circumstances, market conditions and customer needs change. Supply chain management allows a company to focus on its core activity (i.e. to win games for football clubs) which encompasses unique competencies and skills (e.g. the coaching of players), and to outsource non-core activities (e.g. retailing branded merchandise) to partners in the supply chain who have specific capabilities in those activities (Cox, 1999; Rich and Hines, 1997). Although supply chain responsiveness (Kim, 2009) and supply chain integrity (Mutsikiwa et al., 2012) have been found to be associated with consumer-based brand equity, no model of brand equity to accommodate the brand equity effects that might result from supply chain and retail related activities exists in football. Yet, the actions taken and decisions made by football club management in developing and implementing business including multi-channel retail operations such as sourcing, stocking, and displaying of selected merchandise can enhance or detract from brand equity.

As Lowson (2003) and Perry et al. (2014) explain, merchandise products can be conceptually broken into three categories according to their degree of time-dependency and demand predictability; specifically basic, fashion and fast-fashion products. The first category involves 'basic products' such as plain coloured t-shirts with a team's crest, replica team 
wear, key rings, or memorabilia. These types of goods have little variation in style. Their demand profile is somewhat predictable and they tend to have longer product lifecycles and longer shelf-lives. The second category is the 'fashion product' category. For example, a new football kit designed for winter weather will have unpredictable demand profiles with shelflife ranging between 12 and 25 weeks (Lowson, 2003; Perry et al., 2014). Similarly a kit designed for the European games will have shorter product lifecycle than one designed for the domestic league. Fashion product ranges change seasonally in order to enhance consumer purchase stimulus and probability of purchase (Hendry, 2010; O'Cass, 2004; Park et al., 2006). The final category is the fast fashion or 'short season' products such as scarfs designed for specific matches. They have a highly unpredictable demand profiles with a shelf-life between 0-10 weeks (Lowson, 2003; Perry et al., 2006).

Given that logistical functions, i.e. storage facilities, inventory, transportation, packaging and communications (Fernie et al., 2010; Fernie and Sparks, 2014; Sparks, 2007), have to be tailored to each product depending on their predictability, variation and lifecycle to avoid high expenses (Park et al., 2006; Perry et al., 2014), football clubs are constantly exposed to changing supply and retailing conditions. Football clubs have to ebb and flow between 'lean' and 'agile' supply chain strategies in order to be profitable. A 'lean' supply chain is essentially a streamlined approach and a system of pre-established interconnected and interdependent partners that operate in unison to accomplish supply chain objectives. This type of supply chain is suitable to basic products given its focus on minimizing costs. It can be seen as more appropriate in competitions such as national championships, as locations and opponents are decided well in advance and hence cost effective supply chains and distribution channels can be planned for.

On the other hand being agile and responsive implies that the supply chain can handle unpredictability - and a constant stream of new, innovative products-with speed and 
flexibility (Abernathy et al., 2006; Perry et al., 2014; Sparks, 2007). For instance if a football club reaches the Champions' League Final there will be large and sudden demand for their merchandise; no access to merchandise will result in disappointed fans, too much merchandise will result in dissatisfied shareholders left with unsold stock. In such situations, ownership, control and price of products are negotiated fiercely across a variety of intermediaries, with the hope of creating value for all parties involved including consumers (Fernie et al., 2010; Fernie and Sparks, 2014; McFarland et al., 2008; Sparks, 2010). Thus there are a number of exploratory research questions (RQ) we can address in the area:

- RQ1: What products do football clubs sell?

- RQ2: What are football clubs' main target markets?

- RQ3: Why do football clubs retail merchandise?

- RQ4: How do football clubs sell their products?

- RQ5: What are football clubs' distribution channels?

This paper has implications for research and management as it enables a better understanding of the way football clubs retail their merchandise and identifies best practice in retailing football clubs' branded merchandise.

\section{Methodology}

A multiple case study research design was adopted, drawing on primary and secondary data collected across professional football club organisations (in a similar fashion to Kolyperas et al., 2015; Hamil and Morrow, 2011). Qualitative, case based research is the most suitable approach for exploratory investigation in this new stream of research investigating retail branding in football clubs. The core of this study is the 22 Scottish professional football clubs from the 2013/2014 season competing in the Premiership and Championship administered by the Scottish Professional Football League (SPFL), as presented in table 1. This case sample is 
deemed suitable for the research as it groups a variety of football clubs distinct by their size, tradition, popularity and business operations, and it focuses on a particular national football context which has been found to condition business operations (Habisch et al., 2005).

[Insert Table 1 about here]

The empirical approach chosen involved three different stages of qualitative analysis. These three stages gradually investigate retail branding in football clubs by analysing (1) publicly available information on football clubs' retail facts and activities, (2) type of merchandise retailed and (3) interviews with football club retail managers and supply chain partners on branding and retailing strategies.

The preliminary stage involved a content analysis of publicly available information including annual reports, brochures and official websites. The content analysis undertaken followed guidelines of previous researches on professional cycling and rugby respectively (Morrow and Idle 2008; O'Brien and Slack, 2003) and concerned merchandise supply chains (partners), independent/commercial tangible stores (location), merchandise catalogues (distribution location), e-commerce shopping, co-branding, and merchandise retailed (type of products). This uncovered retail merchandise strategies deployed by each club, consistent with the research of Couvelaere and Richelieu (2005).

As a second stage of data collection, concerned with the varieties of merchandise retailed by each club, clubs' official online stores were reviewed between December 2013 and May 2014 while all Scottish-based physical retail stores were also visited. This was followed by direct telephone contact with key data managers from each club surveyed to ensure reliability and coverage of information. Further to the qualitative approach undertaken a quantitative analysis of data was performed to synthesize the information regarding the type of merchandise retailed. The number and type of product retailed by each football club was recorded allowing a comparison between clubs from the Scottish Premiership and 
Championship using independent t-test, as well as between types of product using paired sample t-test in SPSS 21.0.

The third stage involved semi-structured interviews, these focusing on retail strategies, activities and partners of football clubs. The empirical data set consisted of transcripts of 11 qualitative thematic interviews with managers responsible for retail and other supply chain activities in football clubs. Seven professional football clubs in Scotland were selected to investigate their rationale for the deployment of particular retail merchandise strategies. These clubs were chosen as they were identified in the secondary desk-based research as having different retailing strategies: Celtic, Inverness Caledonian Thistle, Dundee, Dundee United, Falkirk, Hamilton Academical and Partick Thistle. Celtic Football Club is the most successful club within the leagues analysed ${ }^{1}$ and was the only club to negotiate directly with Nike. Inverness Caledonian Thistle Football Club was chosen as it represented an integrated supply chain. The remainder of the clubs were selected as they all had different supply chain partners. In addition, 4 supply chain partners were selected given their relation to the retail merchandise strategies of football clubs. The interviews were all audio recorded and then transcribed verbatim. Interview transcripts were sent to all participants to review and add additional comments, enhancing the validity of the analysis. The transcribed data was coded and thematically organised using the qualitative data analysis software NVivo 10. Each theme is represented individually in table 2.

[Insert Table 2 about here]

\section{Limitations}

This methodology is limited to retail activities across 22 SPFL clubs. While this design helps to understand the organisational aspects of retailing within elite Scottish football clubs, it leaves open the question as to how retail branding strategies occur in different national football settings and ultimately within different club organisations and structures. This 
problem has frequently been raised as criticism of designs that adopt a particular national perspective, but we argue that it is necessary to understand how retail branding strategies unfold among football organisations within the same league (i.e. that operate under the same rules and institutional framework) before focusing on its international development and possible variations amongst football clubs from different countries. The research is exploratory in nature and as such the generalizability of conceptual analysis and its implications for other football club organisations may be limited. The retail branding strategies identified are inevitably based on the empirical findings/information collected by the SPFL clubs, and thus may not reveal how retail branding strategies evolve in other organisations from different sport industries and nations.

\section{Findings}

The research findings are split into two sections. The first section under 'retail branding strategies' provides answers to the first three research questions that focus on the types of product retailed by football clubs, their main target markets and the reasons why they retail merchandise. The second section under 'distribution channels and partners' presents ways through which football clubs retail merchandise and synthesizes their distribution channels, offering insights into the fourth and fifth research questions.

\section{Retail branding strategies}

Three main types of products are merchandised by Scottish football clubs: basic, fashion and short season. At the time of data collection, Scottish football clubs merchandise an average of $20.6(S D=24)$ basic, $21.9(S D=20.5)$ fashion and $3.6(S D=6.5)$ short season products. Raith Rovers, Aberdeen and Inverness Caledonian Thistle retailed high numbers of short season products during the time of data collection. In terms of merchandise retailed, Celtic Football Club retail more merchandise than any other club analysed (112 basic, 92 fashion, and 17 
short season). Scottish football clubs competing in the Scottish Premier League retailed significantly $(\mathrm{t}(20)=2.47, \mathrm{p}<.05)$ more fashion products $(\mathrm{M}=30.8, \mathrm{SD}=23.3)$ compared to clubs competing at Scottish Championship level $(\mathrm{M}=11.3, \mathrm{SD}=9.5)$.

Three main target markets have been identified: male, female and children, with unisex products being counted as both male and female. Products for male supporters $(\mathrm{M}=28.4, \mathrm{SD}=22.7)$ were significantly $(\mathrm{t}(21)=6.04, \mathrm{p}<.001 ; \mathrm{t}(21)=5.40, \mathrm{p}<.001)$ more prevalent than products for female $(\mathrm{M}=12.2, \mathrm{SD}=11.4)$ or children $(\mathrm{M}=18, \mathrm{SD}=16.2)$, the latter being significantly more common than female products $(\mathrm{t}(21)=4.04, \mathrm{p}=.001)$. Scottish football clubs competing in the Scottish Premier League retail significantly $(\mathrm{p}<.05)$ more products for male $(M=38.7, S D=24.6)$, female $(M=17, S D=13.1)$ and children $(M=26.6$, $\mathrm{SD}=16)$ compared to clubs competing at Scottish Championship level, respectively for male $(\mathrm{M}=16, \mathrm{SD}=12.2)$, female $(\mathrm{M}=6.5, \mathrm{SD}=5)$, children $(\mathrm{M}=7.8, \mathrm{SD}=9.3)$.

Within these three product categories, previously manufacturers have tried to introduce more female merchandise in the past but this has failed due to lack of demand. Now, it seems clubs retail unisex merchandise often resulting in no clear distinction between male and female products.

'We actually did a ladies kit but most women bought an extra-large boys shirt...so we introduced unisex wear' (Just Sport, personal communication, March 13, 2014).

Through their community football programs, clubs also saw retailing children's merchandise as contributing to the development of lifelong fans.

\footnotetext{
'The child market is where we want to be, it's a heart and minds business. If you get your kid from age 5, and they will still be wearing it at 15 and 25 and still be coming along to our games' (Dundee United FC, personal communication, February 26, 2014).

'They [parents] buy their kids Motherwell strips because they have become a fan due to their local community coaching session involvement' (Provan Sports, personal communication, March 12, 2014).
} 
Findings also indicate the importance of specific target markets when it comes down to merchandise selection and assortment. Clubs have introduced fashion ranges of merchandise aimed for 'die-hard' supporters or the older generation.

'It maybe goes for an older market and also somebody who wants to have our new stuff but doesn't want to go and shout it from the top of the roof tops or support the club out with match days' (Celtic FC, personal communication, February 21, 2014).

According to interviewees the importance of retailing merchandise is to build the football club brand equity with the general public as most clubs' revenues generated from retailing merchandise is minimal.

\footnotetext{
'Our margins are not remarkable. It generates money which is great but I think it's important to realise the merchandise strategy has added value for our brand awareness and a way for the fans to represent their club' (Falkirk FC, personal communication, Mark 5, 2014).
}

Celtic Football Club were the only club who stated that revenue generated from retailing merchandise is a considerable contributor to their income. This may be due to Celtic managing many stores with high numbers of merchandise retailed, this generating substantial sales in addition to their revenue received from Nike.

'There is a business that's generating about $£ 15-20$ million a year in terms of merchandising as part of our own sales and the Nike income' (Celtic FC, personal communication, February 21, 2014).

In addition, several respondents highlighted the importance of on field performance to demand stimulation. Achieving significant sporting results (e.g. reaching cup finals) can generate substantial revenue and impact the logistic of manufacturers and clubs.

'You can have clubs who have 3,000 people going every week, and then they get to a cup final and they have 25,000 people' (Celtic FC, personal communication, February 21, 2014).

Due to this high demand, manufacturers produce short season products in batches to ensure fans can affiliate with the club. This explains why Raith Rovers, Aberdeen and Inverness 
Caledonian Thistle retailed high levels of short season products during the secondary data collection, with each club reaching a cup final during that period. The manufacturers were mainly UK-based to ensure as short a lead time as possible given that clubs only know their competitors weeks in advance.

'Short term products like our cup final plain t-shirts...Usually they're [manufacturers] all within the UK so we are ready to order and turn it around quickly' (Inverness Caledonian Thistle FC, personal communication, February 25, 2014).

Also, during successful periods most clubs tolerate street vendors retailing counterfeit products which include fake professional football club badges, but noted that their own badges were licensed.

'It is not a big deal and the guy is just making a living and the wee guy just stands on the street and he is not within close range...we do have our badge and that is registered' (Partick Thistle FC, personal communication, February 28, 2014).

\section{Distribution channels and partners}

Basic and short season products for all clubs were sourced from various UK manufacturers. However, team wear and fashion merchandise have various 'middlemen' in distribution. For example, clubs who were retailing Nike, Joma, Diadora or Puma manufactured merchandise have an additional partner in their distribution. Of the 22 SPFL clubs investigated, seven clubs showed integrated supply chains, managing their retailing of merchandise independently, while fifteen clubs outsourced their retail operations (10 entirely and 5 partially). Arrangements with the outsourcer involve managing the clubs' retail stores, online retail stores, retail human resources and/or logistical mix functions.

Findings reveal that clubs differed in the ways in which they adopt and execute their merchandise retailing. The various distribution channels are summarised in Figure 1. Few clubs or outsourcers obtain merchandise directly from their brand manufacturer. Many clubs obtain merchandise from intermediaries who have manufacturing capability or manufacturing 
subcontractors. All clubs manage online retail stores except Hamilton Academical Football Club which views the demand for online store to be low.

[Insert Figure 1 about here]

SPFL clubs associate with world renowned sports brands as clubs believe their fans admire the sport manufacturers' prominence and quality. To gain such access football clubs have to go through intermediaries ${ }^{2}$ who have contracts with manufacturers. Usually, corporate sport wear manufacturers do not deal with small clubs directly as it is logistically expensive.

'There is a quality association...They [fans] want to wear Nike or Puma because they see Ronaldo wearing it and players around the world wearing it. So it has an association and it looks better than a lesser brand' (Hamilton Academical FC, personal communication, March 4, 2014).

'We simply just do not do enough volume. It would just not interest them' (Dundee United FC, personal communication, February 26, 2014).

Intermediaries can meet sudden consumer demand due to short lead times and clubs also receive guaranteed revenue. Intermediaries obtain and store in bulk pre-manufactured merchandise and then personalise the garments to clubs' requirements, generating the short lead time.

'Short lead time because we are carrying the transfers and that is all that needs to be done to the garment' (Provan Sports, personal communication, March 12, 2014).

Clubs which do not utilise intermediaries outsource retailing responsibilities to external retailers or do business independently. There were two main motives for clubs to outsource retailing responsibilities. It can either help clubs focus on other commercial responsibilities or it can also be implemented to gain retailing expertise which in turn will improve retail service and performance. 
'There is not very many of us here and we have different hats that we all wear at the one time. So in that respect, the retail operation worked best for us to focus on other commercial responsibilities' (Dundee United FC, personal communication, February 26, 2014).

'Effectively we are specialists coming in to do this for them...We predict stock, we display stock, we market stock, we make sure our stock is kept tight together as possible whilst giving the right service to the fans'(Provan Sports, personal communication, March 12, 2014).

In addition, certain clubs employed integrated supply chains. Such integration allowed clubs to monitor their partner's behaviour as well as to cut down costs.

'Were very conscious of where the product gets made and we've got strict audit standards on everything our partners do' (Celtic FC, personal communication, February 21, 2014).

'It's purely down to cost. Commissions that were demanded by the companies really just eat into our profit' (Hamilton Academical FC, personal communication, March 4, 2014).

Indeed, clubs utilising intermediaries or outsourcers were dependent on their partners to ensure retailing laws are adhered to.

'I think the problem that Nike directly had as far as we could tell in the main had been dealt with, it is in the past and we think it is dealt with. We cannot monitor the situation as we do not have the resources so we rely on them' (Dundee United FC, personal communication, February 26, 2014).

'We wouldn't know if the factories we are dealing with are certified' (Provan Sports, personal communication, March 12, 2014).

Football club size seems to play a role in retail branding. As an example, Celtic Football Club has a 'Marketing Sponsorship' deal and negotiates with Nike directly. This is where Nike sponsor and co-brand with high profile clubs with high merchandise sales to promote their own brand.

'Your sponsorship level is with teams like ourselves and Barcelona will have. Our strips are produced and manufactured directly by Nike and they pay us millions of pounds to be our manufacturer... We will order in such large quantities they will want to deal with us as the more we sell the more we promote them with their logo on our merchandise' (Celtic FC, personal communication, February 21, 2014). 
Nike obtained the rights to sell Celtic merchandise worldwide to commercial retail stores as part of their retail marketing agreement with Celtic. This allows Nike to recover the money invested into Celtic.

'They supply the club and they have agreement for global distribution... So they then have the right to whoever to sell that product and recoup some of that money that they pay them' (Genesis Sport, personal communication, April 1, 2014).

When the discussion comes down to retail stores, it is clear that the physical retail stores generate more purchasers than online retail stores. However, clubs were starting to notice an increase in online purchase popularity while online stores enable fans who live far away to buy merchandise and associate with the clubs.

'Last year $12.2 \%$ of our sales was over the internet, this year $18.3 \%$ for Motherwell. However, no jump in turnover, just a movement in the way people buy' (Provan Sports, personal communication, March 12, 2014).

'They can go online and do it and that's where we maybe appeal to our fair-weather fans who can't come to the shop as they stay a fair distance away' (Dundee United FC, personal communication, February 26, 2014).

\section{Discussion}

SPFL clubs showed that building brand equity was the principal motive for retailing merchandise. The receipt of income from retailing merchandise is considerable for Celtic Football Club, as similarly found by Worsley (2001). However, Celtic gains a competitive advantage by creating widespread brand awareness through retailing on a global scale with Nike. Nike receives brand awareness as a consequence of Celtic's worldwide fan base by obtaining their brand logo on Celtic's retailed merchandise. Both brands were reciprocally cooperating allowing them to perform at a high level. These results were also identified by Motion et al. (2003) whilst investigating the successful co-brand partnership of Adidas and 
the New Zealand Rugby Team. Consistent with previous literature (Couvelaere and Richelieu, 2005; Kwon et al., 2008; Motion et al., 2003), clubs cooperated with renowned sports brands to associate with the quality perceived by the manufacturer.

As far as target markets are concerned, high-street sport retailers can be guilty of 'marketing myopia', not noticing the growth of the female sports goods market (Sparks, 2008). However, while most clubs have sought to respond to the female market, many retail an unsuitable range of products making it difficult for females to affiliate easily with their club. According to Sparks (2008), females desire a contemporary hybrid of fashion and sportswear which renowned sport brands manufacture. Therefore, clubs associated with intermediaries offering these products consequently gained a competitive advantage. Clubs also view retailing children's merchandise as imperative to gaining new supporters which in time may generate various forms of future commercial revenue (Couvelaere and Richelieu, 2005).

Furthermore, according to the interviewees, children's involvement in clubs' community football programmes has resulted in increases numbers of children purchasing club merchandise and developing a stronger affiliation with the club. Commitment to a leisure activity leads to people developing social identity (Green and Jones, 2005), and it is suggested that clubs retail branded school merchandise such as school bags and pencil cases to encourage children's social identity as a supporter of their club. However, one participant stated that children were unable to display SPFL club branded merchandise within schools. An unwritten rule was put in place by multiple Scottish City Councils (including Edinburgh, Falkirk and Glasgow), the aim being to prevent 'trouble in the classroom' through fans visibly expressing their affiliation and loyalty. This self-generated social control may be seen as limiting clubs revenue and children brand affiliation. 
Another issue that was raised by participants is the existence of counterfeit merchandise which also limits clubs' potential revenue. Celtic Football Club alone reported $£ 11$ million worth of counterfeited merchandise was confiscated in 2013 (Celtic Plc, 2013). Licensing has prevented infringement in the past, as evidenced in the case of The Arsenal v. Reed (Bill, 2004; Shemtov, 2007). However, in the Scottish case, Dyer v. Rangers Football Club (Waelde et al., 2013), the vendor was acquitted for retailing counterfeited merchandise which may be the reason for vendor toleration among some clubs. SPFL clubs are clearly vulnerable to street vendors even if their badges were licensed.

In term of retail arrangements, indirect stores were minimally operated by SPFL clubs due to high expense but it is recognised that these can increase brand awareness (Brun and Castelli, 2014). Certain intermediaries retail clubs' merchandise in indirect stores, thus exposing club brands to a wider audience and supporters/followers. Direct club stores can be managed independently by the club, or be managed by outsourced retailing professionals or intermediaries to gain retailing expertise. In line with research highlighting the specific capabilities of outsourcers in the supply chain (Cox, 1999; Rich and Hines, 1997), the outsourcing of functions by SPFL clubs allows for increases in service level or enables clubs to focus on other key activities. Bristow and Sebastian (2001) identified high service level relating to increasing consumer purchase intentions as providing a reason for using outsourcers or intermediaries. Clubs could increase revenue from retailing independently as they were restricted to outsourcers or intermediaries delivering minimum royalties. However, as discussed by Fernie and Sparks (2014) in respect of the general retail environment, it is a matter of balancing between profit and service level. Here SPFL clubs prefer to ensure high service levels, this being shown to increase brand equity (Davies et al., 2008). 
Long lead times occur when organisations negotiate directly with manufacturers, such as Aberdeen and Football Nation who negotiate directly with Adidas. This is due to manufacturing taking place thousands of miles away. As a result during periods of high demand clubs cannot receive sufficient products in time. A similar problem was identified by Fernie and Temple (2014) when analysing the partnership of Adidas and Schuh in the footwear industry. However, co-branding with Adidas in particular generates a strong brand image (Couvelaere and Richelieu, 2005; Motion et al., 2003). Alternatively, certain intermediaries have the ability to manufacture bespoke products on behalf of manufacturers. This agile supply chain enables clubs to meet sudden consumer demand for bespoke products, increasing satisfaction as a result and developing fan affiliation (Hendry, 2010). Furthermore, clubs may minimise storage expenses by holding low inventory. Sparks (2007) states that wholesalers are not required due to clubs having their own storage facilities within their own stadiums. However, clubs utilising intermediaries do not require storage facilities at all, hence reducing expenses.

In terms of monitoring supply chains, clubs utilising integrated supply chains were able to closely monitor partners and avoid possible consumer confrontation. On the other hand, clubs utilising intermediaries or outsourcers were dependent on their partners to ensure retailing laws are adhered to, something which has caused problems previously (Spar and Burns, 2002; Sparks, 2007). Indeed, those who had merchandise manufactured by renowned manufacturers had little communication with their supply chain partners. This questions if clubs' values and CSR initiatives were being adhered to by supply chain partners.

Retail management implications can be highlighted from this research. This study recommends to football clubs of small or medium size to initiate partnerships with intermediaries, as this is the optimal strategy to achieve the objective of building brand 
equity. Firstly, intermediaries retail a renowned manufacturer's merchandise, thus allowing clubs to provide the quality that they believe their fans demand. Intermediaries are also wellpositioned to cope with the unpredictability of football by being able to react to sudden changes in consumer demand in contrast to manufacturers operating without an intermediary. This increases the opportunity for supporters to consume merchandise, in turn increasing revenue and brand equity. Intermediaries can also more easily obtain merchandise which encourages female affiliation, potentially increasing revenue and brand equity as a result.

However, there are limitations to utilising intermediaries. Ensuring clubs do not generate negative brand affiliations is not easy due to a lack of control over supply chain partners. In contrast clubs with integrated supply chains are in a position to monitor their partners. Similarly, counterfeited merchandise poses a risk to clubs as fans may associate the club with a product whose quality is not guaranteed, with a resultant negative impact on SPFL clubs' desire to build brand equity. At present a licensed badge is the only form of brand protection SPFL clubs possess but this system has limitation (Waelde et al., 2013). We recommend enhanced brand protection for football clubs, to be achieved through better monitoring of intermediaries, strengthening partnerships, discussion with street vendors, educating fans, and punitive sanctions against counterfeiters; some of which may be carried out by supply chain partners themselves or by professional leagues.

Research implications can also be highlighted. There is an opportunity to conduct future research using the present findings in a different national or cross-national industrial context, replicating and developing it further to suit other institutional settings and/or sports. Indeed, a similar study in another league with clubs of similar size and market base such as in Belgium, Denmark or Ireland would enable a comparison of results and further contribute to the body of knowledge. An analysis of the retail branding strategies of football clubs 
competing in the English Premier League would also be of interest and might provide similar characteristics to the strategies used by Celtic Football Club, which differs from the practices of the other SPFL clubs. In addition, the extent to which football club fans demand a particular quality of football club merchandise to be retailed is an important area to be investigated. To date, clubs have assumed their fans demand high quality merchandise, despite the absence of market research. If proven wrong the presence of intermediaries in supply chains may be under threat. Focus groups specifically investigating fans of various football clubs would be an appropriate method of analysis. The results of this study show licensing is the only form of protection enjoyed by the majority of SPFL clubs in terms of their brand image, despite the fact that this has been shown previously not to be effective. Future research could investigate methods through which professional sports clubs can protect their brand and of the opportunities to preventing infringement in their current form. Cross comparison across different leagues should be analysed to assess the most appropriate method of brand protection.

\section{Conclusion}

The purpose of this study was to analyse retail branding strategies among professional football clubs. This is the first study to empirically examine the interconnected world of retail and branding in football clubs, and to provide insights into why football clubs retail merchandise and how do they do so, by identifying partners in distribution channels. It also highlights the specificities of the football environment: a seasonal operating cycle, influenced by on-pitch performance, sudden and unpredictable demand and a focus on football fans' brand affiliation, all of which have implications for retailing and selecting supply chain partners. 


\section{Notes}

${ }^{1}$ Since its inception in 1975/76, the SPFL (previously the Scottish Premier League and prior to that the Premier League) has been won by either Celtic or Rangers in 36 out of 41 seasons, with both clubs also dominating financially. However, following administration and then liquidation, Rangers FC was relegated to the third division for season 2012-2013, and was not therefore part of the analysis focussing on the two top tier clubs in 2013-2014 (Morrow, 2015).

${ }^{2}$ JustSport (Group) Ltd, Total Teamware Ltd, Genesis Sports Ltd and JD Sports were stated under interview conditions as being 'agents', 'sub-contractors' and 'licensees'. There are technical differences between each term (Ascoly and Zeldenrust, 2003). It is impossible without reviewing contracts to state exactly which term matches these organisations. Therefore, the term 'Intermediary' is used to encompass these organisations.

\section{Acknowledgement}

The authors would like to thank Stephen Morrow for his assistance in writing this article. 


\section{References}

Aaker, D. A., \& Joachimsthaler, E. (2000). The brand relationship spectrum: The key to the brand architecture challenge. California management review, 42(4), 8-23.

Abernathy, F. H., Volpe, A., \& Weil, D. (2006). The Future of the Apparel and Textile Industries: Prospects and Choices for Public and Private Actors. Environment and Planning A, 38 (12), 2207-2232.

Adamson, G., Jones, W., \& Tapp, A. (2006). From CRM to FRM: Applying CRM in the football industry. The Journal of Database Marketing \& Customer Strategy Management, 13(2), 156-172.

Ascoly, N., \& Zeldenrust, I. (2003). Monitoring and Verification Terminology Guide. Amsterdam: Stichting Onderzoek Multinationale Ondernemingen.

Belch, G. E., \& Belch, M. E. (2004). Advertising and Promotion: An Integrated Marketing Communications Perspective (6th edn). Boston: Mcgraw-Hill.

Bill, K. (2004). Sports and the Law. In J. Beech, \& S. Chadwick (Eds), The Business of Sport Management (pp. 293-230). India: Pearson Education.

Birtwistle, G., \& Freathy, P. (1998). More than just a name above the shop: a comparison of the branding strategies of two UK fashion retailers. International Journal of Retail \& Distribution Management, 26(8), 318-323.

Blanchard, C., Comm, C. L., \& Mathaisel, D. F. (2008). Adding Value to Service Providers: Benchmarking Wal-Mart. Benchmarking: An International Journal, 15 (2), 166-177.

Bobby, D. (2002). Can a sports club be a brand. Sport Business International.

Bristow, D. N., \& Sebastian, R. J. (2001). Holy Cow! Wait Till Next Year! A Closer Look at the Brand Loyalty of Chicago Cubs Baseball Fans. Journal of Consumer Marketing, 18 (3), 256-275. 
Bristow, D. N., \& Sebastian, R. J. (2001). Holy cow! Wait'til next year! A closer look at the brand loyalty of Chicago Cubs baseball fans. Journal of Consumer Marketing, 18(3), 256275.

Brun, A., \& Castelli, C. (2014). Supply Chain Strategy in the Fashion and Luxury Industry. In J. Fernie, \& L. Sparks (Eds), Logistics and Retail Management: Insights into Current Practice and Trends from Leading Experts (pp. 117-148). London: Kogan Page.

Burt, S. L., \& Sparks, L. (2003). Power and competition in the UK retail grocery market. British Journal of Management, 14, 237-254.

Burton, R., \& Howard, D. (1999). Professional sports leagues: Marketing mix mayhem. Marketing Management, 8(1), 36.

Celtic Plc. (2013). Annual Report Year Ended 30 June 2013. Retrieved 21 April 2014 http://www.celtictrust.net/index.php?func=d_home_documents_view\&id=48 accessed on 21.

Chopra, S., \& Meindl, P. (2007). Supply chain management. Strategy, planning \& operation (pp. 265-275). Gabler.

Cliffe, S. J., \& Motion, J. (2005). Building Contemporary Brands: A Sponsorship-Based Strategy. Journal of Business Research, 58 (8), 1068-1077.

Couvelaere, V., \& Richelieu, A. (2005). Brand Strategy in Professional Sports: The Case of French Soccer Teams. European Sport Management Quarterly, 5 (1), 23-46.

Cox, A. (1999). Power, value and supply chain management. Supply chain management: An international journal, 4(4), 167-175.

Davies, D. F., Golicic, S. L., \& Marquardt, A. J. (2008). Branding a B2B Service: Does a Brand Differentiate a Logistics Service Provider? Industrial Marketing Management, 37 (2), 218-227. 
Deloitte (2016), Deloitte Football Money League 2016, Retrieved from http://www2.deloitte.com/uk/en/pages/sports-business-group/articles/deloitte-footballmoney-league.html (accessed 02/02/2016).

Dolles, H., \& Söderman, S. (2013). The network of value captures in football club management: A framework to develop and analyze competitive advantage in professional team sports. In H. Dolles \& S. Söderman (Eds), Handbook of research on sport and business (p. 418-432), Edward Elgar, Cheltenham, UK,.

End, C. M., Diettz-Uhler, B., Harrick, E. A., \& Jacquemotte, L. (2002). Identifying With Winners: A Re-examination of Sport Fans' Tendency to BIRG. Journal of Applied Social Psychology, 32 (5), 1017-1032.

Fernie, J., \& Sparks, L. (2014). Retail Logistics: Changes and Challenges. In J. Fernie, \& L. Sparks (Eds), Logistics and Retail Management: Insights into Current Practice and Trends from Leading Experts (pp. 19-34). London: Kogan Page.

Fernie, J., \& Temple, C. (2014). The Footwear Supply Chain: The Case of Schuh. In J. Fernie, \& L. Sparks (Eds), Logistics and Retail Management: Insights into Current Practice and Trends from Leading Experts (pp. 101-116). London: Kogan Page.

Fernie, J., Sparks, L., \& McKinnon, A. C. (2010). Retail Logistics in the UK: Past, Present and Future. International Journal of Retail and Distribution Management, 38 (11), 894914.

Fink, J. S., Trail, G. T., \& Anderson, D. F. (2002). Environmental Factors Associated With Spectator Attendance and Sport Consumption Behaviour: Gender and Team Differences. Sport Marketing Quarterly, 11 (1), 8-19.

Forbes (2015), Real Madrid Tops Ranking Of The World's Most Valuable Soccer Teams , Retrieved from http://www.forbes.com/sites/mikeozanian/2015/05/06/real-madrid-tops- 
ranking-of-the-worlds-most-valuable-soccer-teams/\#24d83cb83b36 (accessed 02/02/2016).

Gladden, J. M., Irwin, R. L., \& Sutton, W. A. (2001). Managing North American major professional sport teams in the new millennium: A focus on building brand equity. Journal of Sport Management, 15(4), 297-317.

Gladden, J. M., Milne, G. R., \& Sutton, W. A. (1998). A conceptual framework for assessing brand equity in division I college athletics. Journal of Sport Management, 12(1), 1-19.

Green, B. C., \& Jones, I. (2005). Serious Leisure, Social Identity and Sport Tourism. Sport in Society, 8 (2), 164-181.

Gustafson, R. (2001, April 5). Product Brands Look Set to Gain New Advantage. Marketing, p. 20.

Habisch, A., Jonker, J., Wegner, M., \& Schmidpeter, R. (2005).Corporate social responsibility across Europe. Springer Science \& Business Media.

Hamil, S., \& Chadwick, S. (2010). Introduction and Market Overview. In S. Chadwick, \& S. Hamil (Eds), Managing Football: An International Perspective (pp. 3-16). London: Routledge.

Hamil, S., \& Chadwick, S. (2010). Introduction and market overview. Managing Football: An International Perspective, 3-16.

Hamil, S., \& Morrow, S. (2011). Corporate social responsibility in the Scottish Premier League: Context and motivation. European Sport Management Quarterly, 11(2), 143-170.

Harrison, A., \& Scorse, J. (2010). Multinationals and Anti-Sweatshop Activism. American Economic Review, 100, 247-273.

Heere, B., \& James, J. D. (2007). Stepping Outside the Lines: Developing a MultiDimensional Team Identity Scale Based on Social Identity Theory. Sport Management Review, 10 (1), 65-91. 
Heere, B., \& James, J. D. (2007). Stepping outside the lines: Developing a multi-dimensional team identity scale based on social identity theory. Sport Management Review, 10(1), 6591.

Hendry, L. C. (2010). Product Customisation: An Empirical Study of Competitive Advantage and Repeat Business. International Journal of Production Research, 48 (13), 3845-3865.

Hisey, P. (2002). The Return of Sears and Penny. Retail Merchandiser, 42 (8), 33-35.

Hughes, A. (2012). Corporate Ethical Trading in an Economic Downturn: Recessionary Pressures and Refracted Responsibilities. Journal of Economic Geography, 12 (1), 33-54.

Islam, M. A., \& Deegan, C. (2010). Media Pressures and Corporate Disclosure of Social Responsibility Performance Information: A Study of Two Global Clothing and Sports Retail Companies. Accounting and Business Research, 40 (2) 131-148.

Jones, M. A., \& Reynolds, K. E. (2006). The Role of Retailer Interest on Shopping Behaviour'. Journal of Retailing, 82 (2), 115-126.

Kapferer, J. N. (2010). Luxury after the crisis: Pro logo or no logo. The European Business Review, (September-October), 42-46.

Kim, S. W. (2009). An investigation on the direct and indirect effect of supply chain integration on firm performance. International Journal of Production Economics, 119(2), $328-346$.

Kolyperas, D., \& Sparks, L. (2011). Corporate Social Responsibility (CSR) Communications in the G-25 Football Clubs. International Journal of Sport Management and Marketing, $10(1), 83-103$.

Kolyperas, D., Morrow, S., \& Sparks, L. (2015). Developing CSR in professional football clubs: drivers and phases. 
Kwon, H. H., Kim, H., \& Mondello, M. (2008). Does a Manufacturer Matter in Go-branding? The Influence of a Manufacturer Brand on Sport Team Licensed Apparel. Sport Marketing Quarterly, 17 (3), 162-172.

Lee, M. S., Motion, J., \& Conroy, D. (2009). Anti-Consumption and Brand Avoidance. Journal of Business Research, 62 (2), 169-180.

LFP. (2014). About the LFP. Received 17 June 2014 from http://www.lfp.es/en/lfp/history.

Lowson, R. H. (2003). Apparel Sourcing: Assessing the True Operational Cost. International Journal of Clothing Science and Technology, 15 (5), 335-45.

Mamic, I. (2005). Managing Global Supply Chain: The Sports Footwear, Apparel and Retail Sectors. Journal of Business Ethics, 59 (2), 81-100.

McFarland, R. G., Bloodgood, J. M., \& Payan, J. M. (2008). Supply Chain Contagion. Journal of Marketing, 72 (2), 63-79.

Morrow, S. (2003). The People's Game? London: Palgrave.

Morrow, S. (2006). Scottish Football It's a Funny Old Business. Journal of Sports Economics, 7 (1), 90-95.

Morrow, S. (2015). Power and logics in Scottish football: The financial collapse of Rangers FC. Sport, Business and Management: An International Journal, 5(4), 325-343.

Morrow, S., \& Idle, C. (2008). Understanding Change in Professional Road Cycling. European Sport Management Quarterly, 8 (4), 315-335.

Motion, J., Leith, S., \& Brodie, R. J. (2003). Equity in Corporate Co-branding. European Journal of Marketing, 37 (7), 1080-1094.

Müller, J. C., Lammert, J., \& Hovemann, G. (2012). The Financial Fair Play Regulations of UEFA: An Adequate Concept to Ensure the Long-Term Viability and Sustainability of European Club Football? International Journal of Sport Finance, 7 (2), 117-140. 
Mutsikiwa, M., Muzangwa, J., \& Basera, C. H. (2012) The Impact of Supply Chain Integrity on Customer Based Brand Equity: The Case of Seed Co Limited (Zimbabwe). Asian Journal of Business and Management Sciences, 1(10), 17-24.

O’Brien, D., \& Slack, T. (2003). An Analysis of Change in an Organizational Field: The Professionalization of English Rugby Union. Journal of Sport Management, 17 (4), 417448.

O’Cass, A. (2004). Fashion Clothing Consumption: Antecedents and Consequences of Fashion Clothing Involvement. European Journal of Marketing, 38 (7), 869-882.

Park, E. J., Kim, E. Y., \& Forney, J. C. (2006). A Structural Model of Fashion-Oriented Impulse Buying Behaviour. Journal of Fashion Marketing and Management, 10 (4), 433446.

Perry, P., Fernie, J., \& Wood, S. (2014). The International Supply Chain and Corporate Social Responsibility. In J. Fernie, \& L. Sparks (Eds), Logistics and Retail Management: Insights into Current Practice and Trends from Leading Experts (pp. 76-100). London: Kogan Page.

Rich, N., \& Hines, P. (1997). Supply-chain management and time-based competition: the role of the supplier association. International Journal of Physical Distribution \& Logistics Management, 27(3/4), 210-225.

Richelieu, A., \& Pons, F. (2006). Toronto Maple Leafs vs Football Club Barcelona: how two legendary sports teams built their brand equity.International Journal of Sports Marketing and Sponsorship, 7(3), 79-98.

Ruihley, B. J., Runyan, R. C., \& Lear, K. E. (2010). The Use of Sport Celebrities in Advertising: A Replication and Extension. Sport Marketing Quarterly, 19 (3), 143-142.

Shannon, J. R. (1999). Sports marketing: an examination of academic marketing publication. Journal of services marketing, 13(6), 517-535. 
Shemtov, N. (2007). Trade Mark Use in Europe: Revisiting Arsenal in the Light of Opel and Picasso. Journal of Intellectual Property Law and Practice, 2 (8), 557-563.

Smestad, L. (2009). The Sweatshop, Child Labour, and Exploitation Issues in the Garment Industry, Fashion Practice. The Journal of Design, Creative Process and the Fashion, 1 (2), 147-162.

Spar, D. L., \& Burns, J. (2002). Hitting the Wall: Nike and International Labour Practices. Harvard Business School Case, 9-700.

Sparks, L. (2007). Distribution Channels and Sports Logistics. In J. Beech, \& S. Chadwick (Eds), The Marketing of Sport (pp. 342-364). London: Prentice Hall.

Sparks, L. (2008). SweatyBetty: By Women, For Women. In S. Chadwick, \& D. Arthur (Eds), International Cases in the Business of Sport (pp. 61-72). Oxford: ButterworthHeinemann.

Sparks, L. (2010). Supply Chain Management and Retailing. In S. Chadwick, \& S. Hamil (Eds), Managing Football: An International Perspective (pp. 151-167). London: Routledge.

Tapp, A. (2004). E-Managing Sport Consumers. In J. Beech, \& S. Chadwick (Eds), The Business of Sport Management (pp. 394-413). India: Pearson Education.

Tokatli, N. (2008). Global Sourcing: Insights from the Global Clothing Industry - The Case of Zara, a Fast Fashion Retaile. Journal of Economic Geography, 8 (1), 21-38.

Turner, P. (2007a). Marketing in For-Profit and Not-For-Profit Sport Organisations. In J. Beech, \& S. Chadwick. (Eds) The Marketing of Sport (pp. 23-44). India: Pearson Education.

Turner, P. (2007b). Direct, Database and Online Marketing in Sport. In J. Beech, \& S. Chadwick (Eds), The Marketing of Sport (pp. 292-317). India: Pearson Education. 
Waelde, C., Laurie, G., Brown, A., Kheria, S., \& Cornwell, J. (2013). Contemporary Intellectual Property: Law and Policy. Oxford: Oxford University Press.

Wakefield, K. L., \& Wann, D. L. (2006). An Examination of Dysfunctional Sport Fans: Method of Classification and Relationships with Problem Behaviours. Journal of Leisure Research, 38 (2), 168-186.

Walters, G., \& Chadwick, S. (2009). Corporate Citizenship in Football: Delivering Strategic Benefits through Stakeholder Engagement. Management Decisions, 47 (1), 51-66.

Williams, D. E. (2009). The Evolution of E-tailing. The International Review of Retail, Distribution and Consumer Research, 19 (3), 219-249.

Wilson, J. A., \& Liu, J. (2012). Surrogate Brands: The Pull to Adopt an 'Other' Nation, Via Sports Merchandise. International Journal of Sport Management and Marketing, 11 (3), 172-192.

Worsley, J. (2001, October 18). Brand Loyalty vs. Venue Loyalty. Leisure \& Hospitality. Retrieved September 2002 from www.henleycentre.com/press/cut_20011022154033657.phtml. 
Table 1. Scottish football clubs during season 2013-2014

\begin{tabular}{|l|r|}
\hline Football Club & Competition level \\
\hline Aberdeen & Premiership \\
\hline Celtic & Premiership \\
\hline Dundee United & Premiership \\
\hline Heart of Midlothian & Premiership \\
\hline Hibernian & Premiership \\
\hline $\begin{array}{l}\text { Inverness Caledonian } \\
\text { Thistle }\end{array}$ & Premiership \\
\hline Kilmarnock & Premiership \\
\hline Motherwell & Premiership \\
\hline Partick Thistle & Premiership \\
\hline Ross County & Premiership \\
\hline St. Johnstone & Premiership \\
\hline St.Mirren & Premiership \\
\hline Alloa Athletic & Championship \\
\hline Cowd'beath & Championship \\
\hline Dumbarton & Championship \\
\hline Dundee & Championship \\
\hline Falkirk & Championship \\
\hline Hamilton Academical & Championship \\
\hline Livingston & Championship \\
\hline Morton & Championship \\
\hline Queen of the South & Championship \\
\hline Raith Rovers & Championship \\
\hline
\end{tabular}


Table 2. Thematic analysis of football clubs' retail branding strategies

\begin{tabular}{|c|c|}
\hline Higher order themes & Lower order themes \\
\hline \multirow[t]{2}{*}{$\begin{array}{l}\text { Supply Chain Partners } \\
\text { The purpose of supply } \\
\text { chain partners }\end{array}$} & $\begin{array}{l}\text { Outsourcers Utilised } \\
\text { Reasons for outsource partners utilised and supply chain } \\
\text { processes as a result }\end{array}$ \\
\hline & $\begin{array}{l}\text { Integrated Supply Chain } \\
\text { The motives for utilising an integrated supply chain }\end{array}$ \\
\hline \multirow{2}{*}{$\begin{array}{l}\text { Merchandise Value } \\
\text { The importance of } \\
\text { retailing merchandise to } \\
\text { the organisation }\end{array}$} & $\begin{array}{l}\text { Brand Development } \\
\text { Developing the organisations brand through retail of } \\
\text { merchandise }\end{array}$ \\
\hline & $\begin{array}{l}\text { Revenue Stream } \\
\text { Revenue outcomes form retailing merchandise }\end{array}$ \\
\hline \multirow{2}{*}{$\begin{array}{l}\text { Target Markets } \\
\text { Targeting groups of } \\
\text { individuals as an outcome } \\
\text { of merchandise strategy }\end{array}$} & $\begin{array}{l}\text { Adult Market } \\
\text { Effect on the adult market as an outcome of the merchandise } \\
\text { sold }\end{array}$ \\
\hline & $\begin{array}{l}\text { Children's Market } \\
\text { Effect on children's market as an outcome of the merchandise } \\
\text { sold. }\end{array}$ \\
\hline \multirow[t]{2}{*}{$\begin{array}{l}\text { Retail Stores } \\
\text { The approach regarding } \\
\text { retail stores }\end{array}$} & $\begin{array}{l}\text { Commercial Retail Stores } \\
\text { The approach behind selling merchandise in commercial } \\
\text { stores }\end{array}$ \\
\hline & $\begin{array}{l}\text { Online retail stores } \\
\text { The emergence and the importance of online retailing }\end{array}$ \\
\hline \multirow{2}{*}{$\begin{array}{l}\text { On-Field Performance } \\
\text { Retailing during successful } \\
\text { on-field playing } \\
\text { performances }\end{array}$} & $\begin{array}{l}\text { Successful Performances } \\
\text { The outcome of retailing merchandise during periods of on- } \\
\text { field success }\end{array}$ \\
\hline & $\begin{array}{l}\text { Street Vendors } \\
\text { Street vendors retailing counterfeit products }\end{array}$ \\
\hline
\end{tabular}




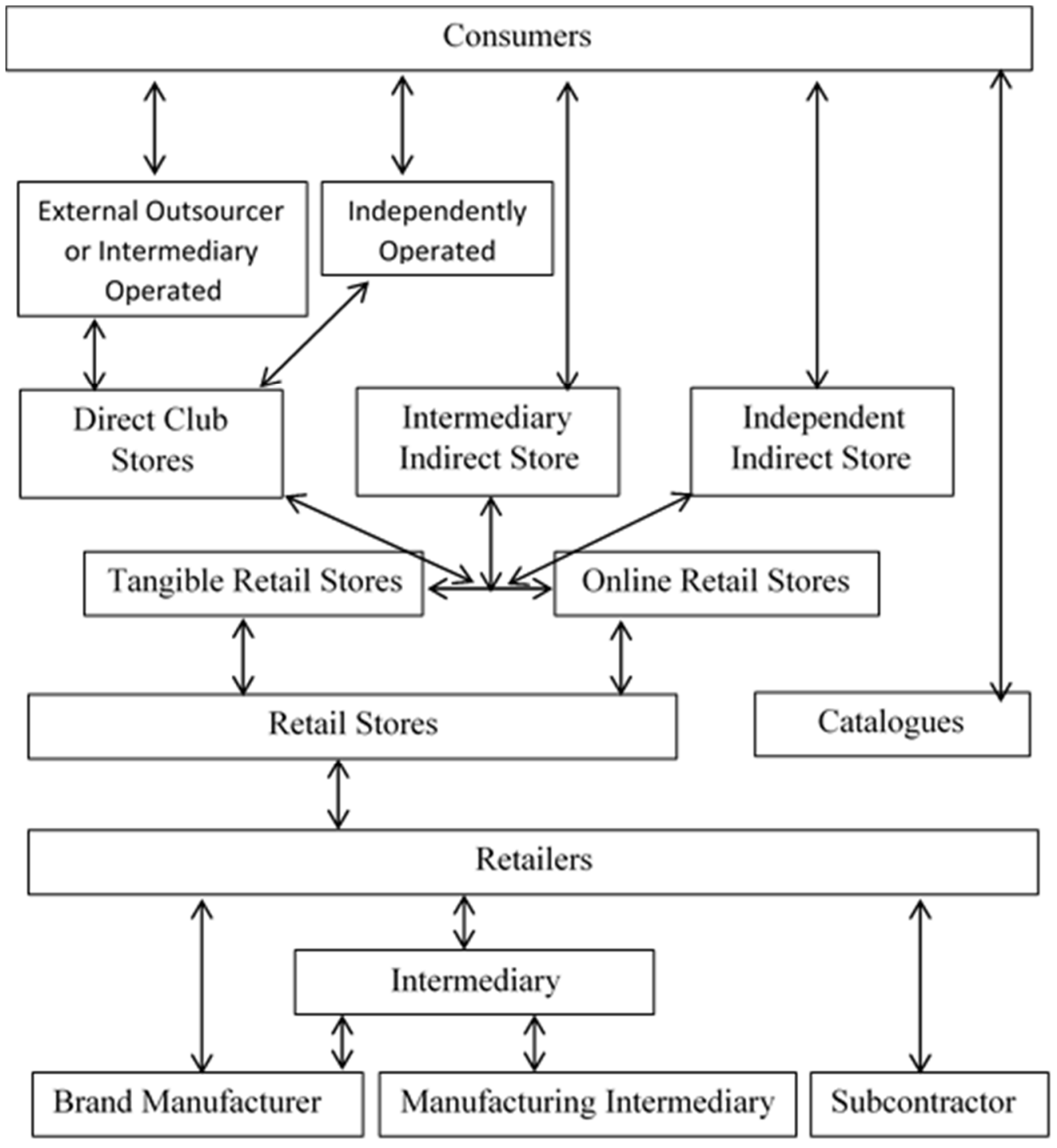

Figure 1. Distribution inter-linkages for SPFL clubs. 